\title{
Geographical patterns of isozyme variation in Mediterranean populations of perennial ryegrass
}

\author{
FRANÇOIS BALFOURIER* \& GILLES CHARMET \\ INRA, Plant Breeding Station, 63039, Clermont-Ferrand, France
}

\begin{abstract}
Twenty-four natural populations of perennial ryegrass, sampled from the Mediterranean area (Italy, Corsica, Sardinia, South of France), have been studied for allelic variation at 13 enzyme loci. The total genetic diversity results mainly from the within-population component whereas a part of the between-population component can be explained by the geographical origins of the populations. Relationships between accessions have been studied using cluster and multivariate analyses such as principal component and discriminant analyses. Finally, the frequency and distribution of the most discriminating allele have been represented on geographic maps. The results indicate that Corsican populations are similar to Italian accessions whereas both French and Sardinian populations differ from all the others. The origins and relationships between each geographical group of accessions are discussed and, taking historical factors into account, we can suggest that Corsican populations have been introduced from Italy to the eastern side of the island.
\end{abstract}

Keywords: genetic diversity, geographic differentiation, isozyme, Lolium perenne L., multivariate analysis.

\section{Introduction}

Perennial ryegrass (Lolium perenne L.) is one of the most important forage grasses used in Northern Europe. It is a self-incompatible, outbreeding species. Its geographical origins are probably located in the Mediterranean area (Malik, 1967; Borill, 1976) where we can find all eight species of the genus Lolium as described by Terrell (1968). Presently, in this part of the world, wild populations of perennial ryegrass can be collected throughout the South of France (Charmet et al., 1990), Italy (Tyler \& Chorlton, 1978; Falcinelli et al., 1987), Corsica (Volaire et al., 1990) and to a lesser extent in Northern Sardinia (Bullitta, personal communication).

In a recent paper, Balfourier \& Charmet (1991) compared agronomic traits of wild populations of perennial ryegrass from Corsica and Italy and noted their potential value for use in the Mediterranean region. The aim of the present paper is to describe the genetic similarity between wild populations of perennial ryegrass coming from this same region by means of isozyme analysis. This method has previously

*Correspondence. proved useful in determining the origin of natural populations (Hamrick et al., 1979). We then try to explain the observed geographical pattern of the genetic variability, taking into account the history of the region.

\section{Materials and methods}

\section{Plant materials}

Twenty-four wild populations of perennial ryegrass were chosen in the Mediterranean area at sites ranging from latitude $40^{\circ}$ to $46^{\circ}$ North and longitude $4^{\circ}$ to $16^{\circ}$ West. Figure 1 shows their geographical location: eight populations were sampled in Corsica and, to determine their region of origin, a further 16 populations were sampled from the surrounding regions. Of these 16 populations, four were from North Sardinia, eight from Italy and four from the French Riviera. Populations were chosen so as to represent the maximum of the agronomic and geographical diversity as reported in a previous paper (Balfourier \& Charmet, 1991).

Each population was collected as seed from at least 50 plants taken from an ecologically homogeneous area of $100-1000 \mathrm{~m}^{2}$. These conditions are thought to yield 


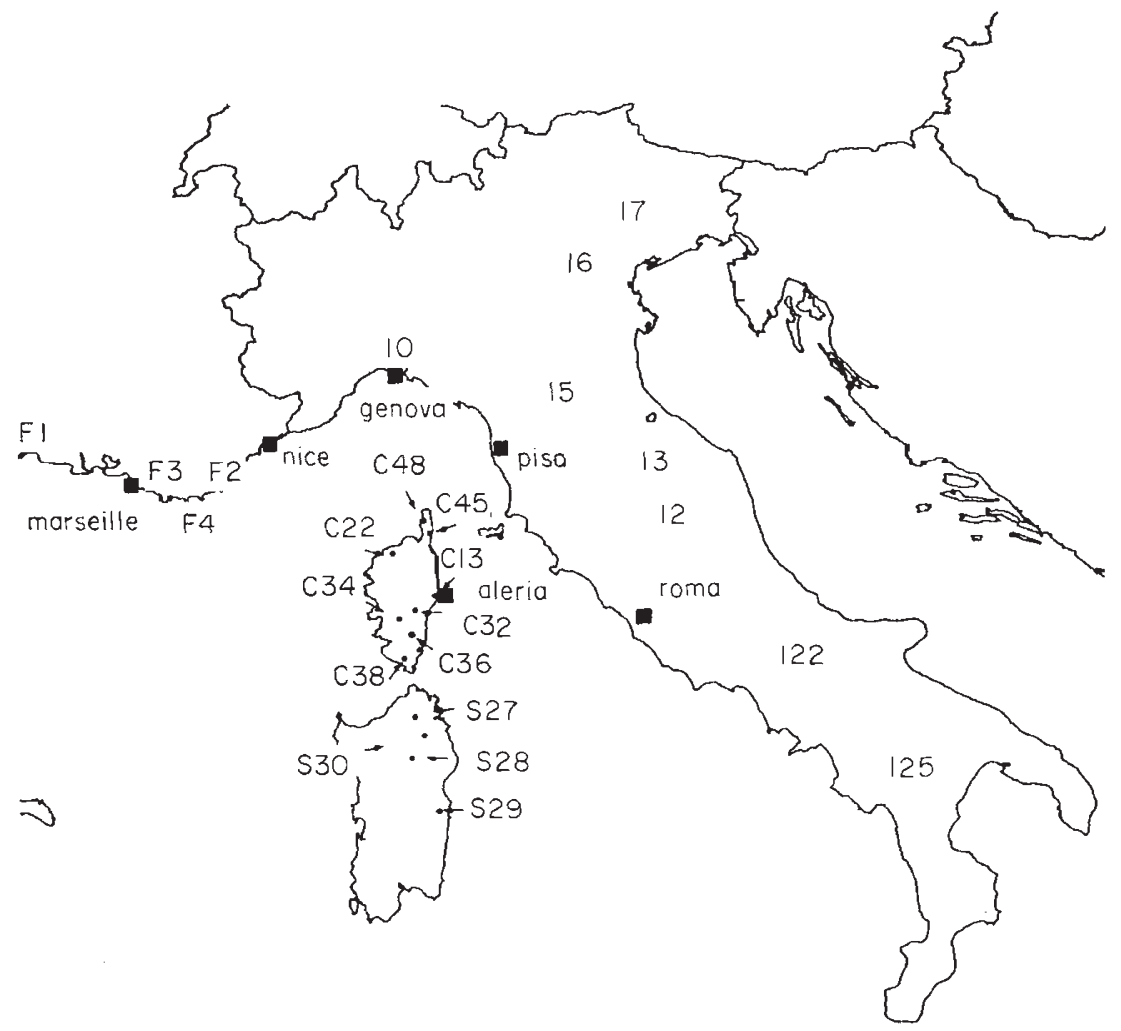

Fig. 1 Location map of the 24 populations of perennial ryegrass.

a sample of seeds representative of the original panmictic populations (Tyler et al., 1984). Table 1 gives the origin and the accession number of the 24 populations.

\section{Isozyme electrophoresis}

From each accession, approximately 75 plants were studied using isozyme electrophoresis techniques according to Hayward \& Mc Adam (1977), Ostergaard et al. (1985), Pollans \& Allard (1985) and Greneche et al. (1991). Slices of two starch gels and two different buffer systems were used and permitted the study of 11 enzyme systems, giving 13 readable loci. Histidine/ citrate buffer was used for acid phosphatase (ACP, E.C. 3.1.3.2), isocitrate dehydrogenase (IDH, E.C. 1.1.1.42), malate dehydrogenase (MDH, E.C. 1.1.1.37), phosphogluco-isomerase (PGI, E.C. 5.3.1.9.), phosphogluco-mutase (PGM, E.C. 2.7.5.1.), 6-phosphogluconate dehydrogenase (6-PGDH, E.C. 1.1.1.44) and shikimate dehydrogenase (SKDH, E.C. 1.1.1.25). Tris-citrate/lithium-borate buffer was used for diaphorase (DIA, E.C. 1.6.4.3), glutamate-oxaloacetate-transaminase (GOT, E.C. 2.6.1.1), peroxidase (PRX, E.C. 1.11.1.7) and superoxide-dismutase (SOD, E.C. 1.15.1.1). Allele nomenclature is that of Hayward \& McAdam (1977), the most anodally migrating one being arbitrarily termed ' $a$ ', the next ' $b$ ' and so on.
Table 1 Accession number and region of origin of the 24 populations

\begin{tabular}{lll}
\hline Accession number & Code & Region of origin \\
\hline 010472 & F1 & Languedoc (France) \\
010958 & F2 & Cote d'Azur (France) \\
011302 & F3 & Provence (France) \\
011303 & F4 & Provence (France) \\
040110 & I0 & Ligure (Italy) \\
040010 & I2 & Toscane (Italy) \\
040011 & I3 & Toscane (Italy) \\
040014 & I5 & Emilie Romagne (Italy) \\
040017 & I6 & Lombardie (Italy) \\
040019 & I7 & Venetie (Italy) \\
040122 & I22 & Pouilles (Italy) \\
040125 & I25 & Basilicate (Italy) \\
011401 & C13 & Haute Corse (Corsica) \\
011410 & C22 & Haute Corse (Corsica) \\
011422 & C32 & Corse du Sud (Corsica) \\
011424 & C34 & Corse du Sud (Corsica) \\
011426 & C36 & Corse du Sud (Corsica) \\
011428 & C38 & Corse du Sud (Corsica) \\
011439 & C45 & Haute Corse (Corsica) \\
011442 & C48 & Haute Corse (Corsica) \\
040127 & S27 & North Sardinia (Sardinia) \\
040128 & S28 & North Sardinia (Sardinia) \\
040129 & S29 & North Sardinia (Sardinia) \\
040130 & S30 & North Sardinia (Sardinia) \\
\hline & & \\
\hline & &
\end{tabular}


Table 2 Summary of genetic statistics for all accessions and for populations grouped by region

\begin{tabular}{|c|c|c|c|c|c|}
\hline & France & Italy & Corsica & Sardinia & $\begin{array}{l}\text { All } \\
\text { accessions }\end{array}$ \\
\hline $\begin{array}{l}\text { Number of } \\
\text { populations }(N)\end{array}$ & 4 & 8 & 8 & 4 & 24 \\
\hline $\begin{array}{l}\text { Number of loci } \\
\text { assayed }\end{array}$ & 13 & 13 & 13 & 13 & 13 \\
\hline $\begin{array}{l}\text { Proportion of } \\
\text { polymorphic loci }(P)\end{array}$ & $\begin{array}{l}81 \\
(77-92)\end{array}$ & $\begin{array}{l}87 \\
(77-92)\end{array}$ & $\begin{array}{l}85 \\
(77-92)\end{array}$ & $\begin{array}{l}81 \\
(77-92)\end{array}$ & 84 \\
\hline $\begin{array}{l}\text { Mean number of } \\
\text { allele per locus }(A)\end{array}$ & $\begin{array}{l}2.29 \\
(1.92-2.62)\end{array}$ & $\begin{array}{l}2.84 \\
(2.46-3.30)\end{array}$ & $\begin{array}{l}2.79 \\
(2.54-3.00)\end{array}$ & $\begin{array}{l}2.39 \\
(2.08-2.77)\end{array}$ & 2.65 \\
\hline $\begin{array}{l}\text { Average expected } \\
\text { heterozygosity }(H)\end{array}$ & $\begin{array}{l}0.283 \\
(0.254-0.327)\end{array}$ & $\begin{array}{l}0.326 \\
(0.279-0.375)\end{array}$ & $\begin{array}{c}0.347^{* *} \\
(0.334-0.367)\end{array}$ & $\begin{array}{l}0.301 \\
(0.244-0.343)\end{array}$ & 0.322 \\
\hline
\end{tabular}

**Significant at 1 per cent level.

Table 3 Wright's $F$ statistics on the 24 populations

\begin{tabular}{lllll}
\hline$F_{\text {it }}$ & $F_{\text {is }}$ & $F_{\text {st }}$ & $F_{\text {sx }}$ & $F_{\text {xt }}$ \\
\hline 0.113 & 0.023 & 0.092 & 0.066 & 0.026 \\
\hline
\end{tabular}

$\mathrm{x}=$ region of origin.

When a new allele was discovered, it became $a^{+}, b^{+}$, $c^{*}, \ldots$

\section{Data analysis}

Allelic frequencies were determined by direct allele counting. Data of individual genotypes were stored in an ORACLE-developed database (Ravel et al., 1992) and standard statistics for characterizing genetic variability were computed for all accessions using the Brosys 1 program (Swofford \& Selander, 1981). The betweenpopulation component $F_{\text {st }}$ (Wright, 1965) was decomposed through a hierarchical $F$ analysis (Wright, 1978) by introducing a between cluster $F_{\mathrm{xt}}$ index and a within cluster $F_{\mathrm{sx}}$ index, the factor $\mathrm{x}$ of classification being the region of origin of the populations.

Cluster analysis was computed on genetic similarity coefficients (Rogers, 1972) using the unweighted pairgroup method with arithmetic averaging (UPGMA). Multivariate relationships among accessions were revealed with principal component analysis (PCA) using a variance covariance matrix derived from allelic frequencies (Sneath \& Sokal, 1973). However, to avoid colinearity problems, only one allele per polymorphic locus was used for multivariate analysis. Finally, a factorial discriminant analysis (Tomassone et al., 1988) was carried out to discriminate populations according to their geographical origin. Graphic representations of multivariate analyses and geographical maps were obtained using the ' $\mathrm{S}$ ' programing environment (Becker et al., 1988).

\section{Results}

\section{Genetic diversity}

Data for individual populations are not presented here but are available on request. Table 2 summarizes genetic statistics on populations grouped according to the different regions and on the populations in total: proportion of polymorphic loci $(P)$, mean number of alleles per locus $(A)$, average expected heterozygosity $(H)$ and their range of variation (given in parentheses). Values for both proportion of polymorphic loci and the mean number of alleles per locus do not differ significantly between regions. Only the $H$ value for Corsica is significantly higher compared with the overall mean.

Table 3 shows Wright's fixation index on the 24 populations (Wright, 1965): $F_{\text {it }}$ (overall), $F_{\text {is }}$ (within populations), $F_{\text {st }}$ (between populations) and the decomposition of this between population component according to the region of origin. The low value of $F_{\text {is }}$ indicates that on average populations are in panmictic equilibrium. The $F_{\text {st }}$ value of 0.092 is in agreement with Hamrick \& Godt $(1989)$, who reported a mean $F_{\text {st }}$ value of 0.098 for 134 outcrossing, wind-pollinated species. The hierarchical decomposition of $F_{\text {st }}$ according to the region, as factor of classification, shows that this factor succeeded in explaining an important part of $F_{\text {st }}$ (about 25 per cent) by a between factor differentiation component.

With the exception of 6-PGD, all the systems are polymorphic and two systems show two readable loci: $A C P \quad 1-2$ and GOT 2-3. A total of 47 alleles were 
found for these 13 loci, not including the unusual observation of putative null alleles. PGI and ACP systems reveal the most polymorphic loci, a result which is consistent with those published on the same species by Greneche et al. (1991). The Fisher test values on geographical origin indicate that some loci (e.g. $A C P-2, G O T-3$ ) and some alleles of these loci (e.g. $\left.A C P-2 \_b, \quad G O T-3 \_b\right)$ are more discriminating between regions.

The 47 allelic frequencies were used to calculate cluster analysis, computed from genetic similarity coefficients (Rogers, 1972) of all 24 populations. From this, the phenogram was drawn (Fig. 2) and three main clusters can be identified: the separation of Sardinian accessions and, to a lesser extent, French accessions is very clear whereas Corsican and Italian populations seem to be grouped together. However, in this last group, we can observe a separation of Italian accessions from Corsican accessions, with the exception of population no. C13 which occurs within the Italian group and no. $\mathrm{C} 22$ which is aside from both groups. In fact, these genetic similarities are quite related to geographical distances. Table 4 shows the matrix of similarity coefficients (Rogers, 1972) averaged by

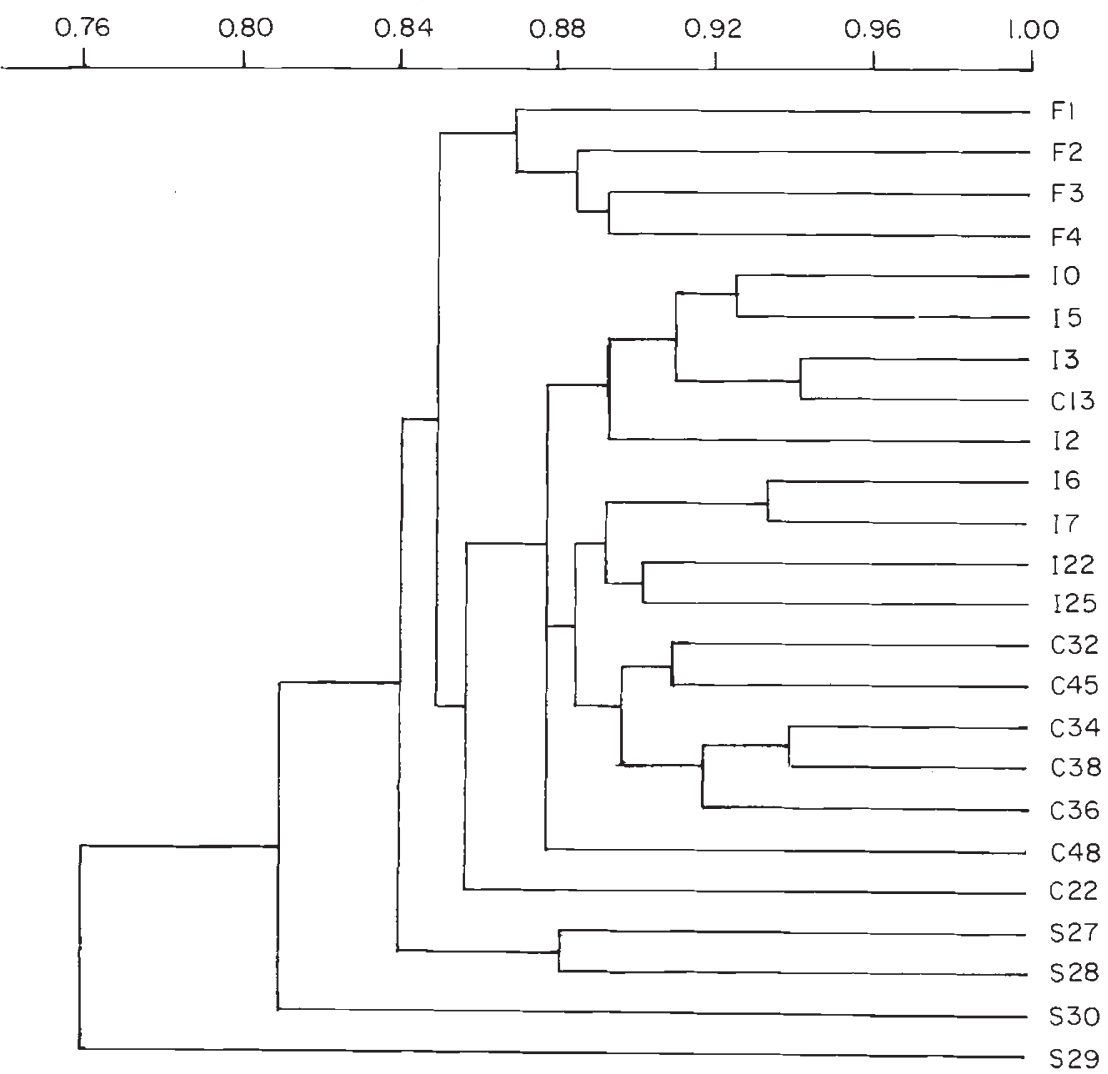

Table 4 Matrix of Rogers' similarity coefficient averaged by region of origin

\begin{tabular}{lllll}
\hline & France & Italy & Corsica & Sardinia \\
\hline France & 0.890 & & & \\
& $(0.871-0.904)$ & & & \\
Italy & 0.869 & 0.900 & & \\
& $(0.835-0.913)$ & $(0.867-0.940)$ & & \\
Corsica & 0.856 & 0.887 & 0.889 & \\
& $(0.798-0.911)$ & $(0.838-0.947)$ & $(0.858-0.948)$ & \\
Sardinia & 0.810 & 0.826 & 0.840 & 0.835 \\
& $(0.729-0.877)$ & $(0.736-0.879)$ & $(0.747-0.907)$ & $(0.791-0.893)$ \\
\hline
\end{tabular}

Ranges are given in parentheses.
Fig. 2 Phenogram of UPGMA cluster analysis based on isozyme allele frequency data, using Rogers' similarity coefficient. 
region or origin and their range of variations. The previous results are confirmed: within the same regional group, populations appear to be similar $(0.900)$ except for that of Sardinia. Between the different regional groups, Corsican accessions seem to be more similar to Italian accession than to French ones whereas Sardinian populations are distinct from those of all other three regions.

Table 5 Mean frequencies of the 12 most discriminating alleles compared with means by region of origin

\begin{tabular}{llllll}
\hline Alleles & $\begin{array}{l}\text { Overall } \\
\text { mean }\end{array}$ & France & Italy & Corsica & Sardinia \\
\hline$A C P-1 \_c$ & 0.453 & 0.410 & 0.333 & 0.425 & $0.775^{* *}$ \\
$A C P-2 \_b$ & 0.318 & $0.609^{*}$ & 0.343 & $0.236^{*}$ & 0.141 \\
$D I A \_b$ & 0.286 & 0.177 & $0.413^{*}$ & 0.274 & 0.166 \\
$G O T-2 \_c$ & 0.005 & 0.000 & 0.007 & 0.008 & 0.000 \\
$G O T-3 \_b$ & 0.751 & $0.945^{*}$ & 0.806 & 0.732 & 0.486 \\
$I D H \_c$ & 0.375 & 0.278 & 0.414 & 0.444 & 0.256 \\
$M D H \_a^{+}$ & 0.003 & 0.000 & 0.005 & 0.002 & 0.005 \\
$P G I \_c$ & 0.040 & 0.021 & $0.094^{*}$ & $0.017^{*}$ & 0.000 \\
$P G M \_c$ & 0.003 & 0.000 & 0.007 & 0.001 & 0.004 \\
$P R X \_c$ & 0.943 & 0.980 & 0.964 & $0.904^{* *}$ & 0.944 \\
$S K D H \_c$ & 0.060 & $0.117^{*}$ & $0.034^{*}$ & $0.039^{*}$ & 0.097 \\
$S O D \_b$ & 0.969 & 0.948 & 0.970 & 0.972 & 0.982 \\
\hline
\end{tabular}

*, **Significant, respectively, at 5 per cent or 1 per cent level.

\section{Geographical pattern of diversity}

For each polymorphic locus, the allelic frequency having the highest $F$ Fisher value (i.e. 12 allelic frequencies) was used in multivariate analyses. Table 5 gives the overall means for these 12 allelic frequencies, in comparison with means calculated on populations grouped according to their region of origin. Some alleles present values which differ significantly between regions. A map depicting the spatial distributions of the $A C P 2 \_b$ allele is shown in Fig. 3, in comparison with the other alleles of the same locus: its frequency is very high on the French Riviera, less important in Italy, rare in Sardinia and shows a clinical north-south variation in Corsica.

Figure 4 shows the projection of each population on the plan, defined by component 1 and 2 of principal component analysis, carried out on these 12 allelic frequencies. Populations are coded according to Table 1; the first principal component, which accounts for half of the total variance (50.9 per cent), separates Sardinian accessions (negative axis score) from Corsican and continental accessions (positive axis score). Therefore, axis 1 represents an approximate south-north axis whereas no clear interpretation is evident for axis 2 which accounts for an additional 18.7 per cent of the variance and separates the French accessions from the Corsican and Italian populations,
Fig. 3 Geographic map representing allelic diversity at the $A C P-2$ locus.

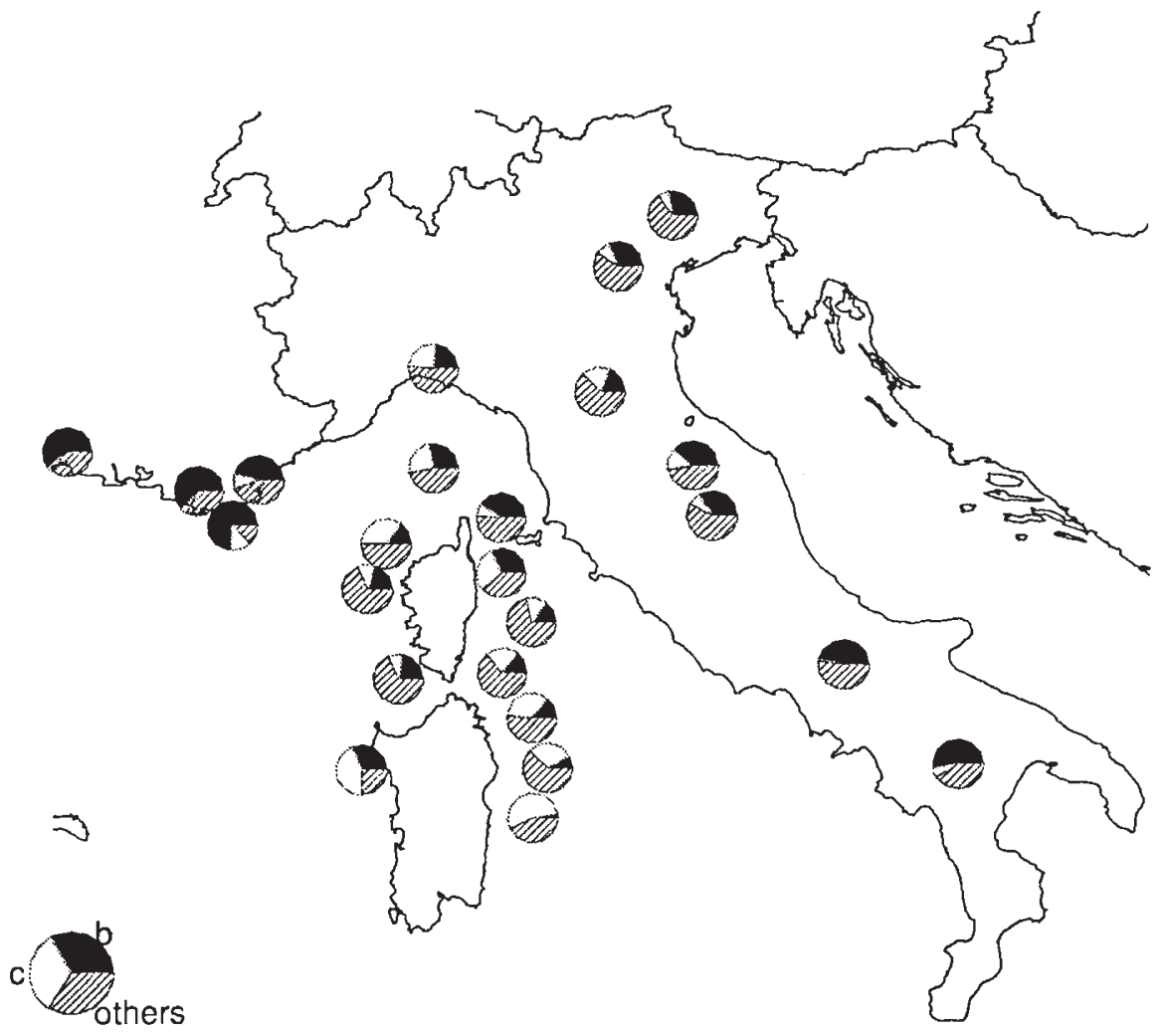




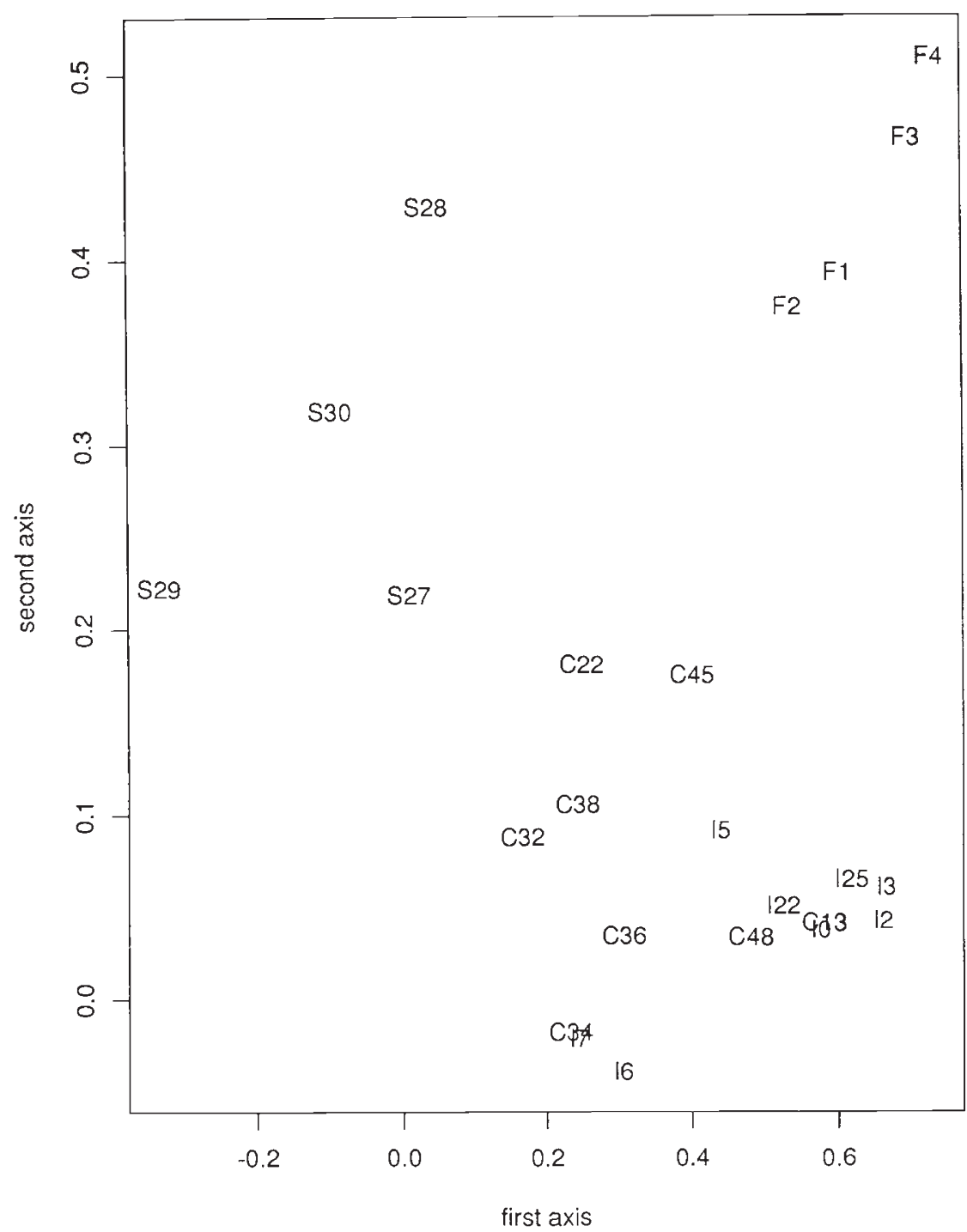

Fig. 4 Graph of the first two components of a principal component analysis, which account for 69.6 per cent of the total variance. Abbreviations used for accessions are listed in Table 1. which remain mixed. In particular, accession no. C13, from the eastern coast of Corsica, and accession no. 48 from North Corsica, are very close to those of Italy. Accession no. C22, from the north-west coast, appears to be the nearest to the French populations. These results are very consistent with those presented on the phenogram (Fig. 2).

Finally, Fig. 5 shows the result of a discriminant analysis; the plan defined by axis 1 and 2 accounts for 89.7 per cent of the total inertia. On this plan, the 24 populations are clearly divided into four distinct groups according to their region of origin. The correlation coefficient of the 12 allelic frequencies with the two first axes of the discriminant analysis indicates that, on the first axis, Sardinian and Italian accessions are mainly discriminated by $A C P-1 \_c$ and $D I A \_b$ alleles whereas on axis 2, $P R X_{-} c$ and $A C P-2 \_b$ alleles separate Corsican from French accessions. As these two axes are not correlated, we can suppose that there is no linkage disequilibrium between the loci.

\section{Discussion and conclusion}

\section{Genetic diversity}

Genetic structures in natural populations of forage grasses have been already reported for Dactylis glomerata (Lumaret, 1984), Festuca rubra (Livesey \& Norrington-Davies, 1991), Cynosurus cristatus (Ennos, 1985) and Arrhenaterum elatius (Ducousso et al., 1990).

For perennial ryegrass, results of isozyme surveys have been published for wild populations from Italy (Hayward, 1985; Arconi et al., 1988) and from 
Fig. 5 Graph of the first two components of a discriminant analysis, which account for 89.7 per cent of the total variance. Abbreviations used for accessions are listed in Table 1.

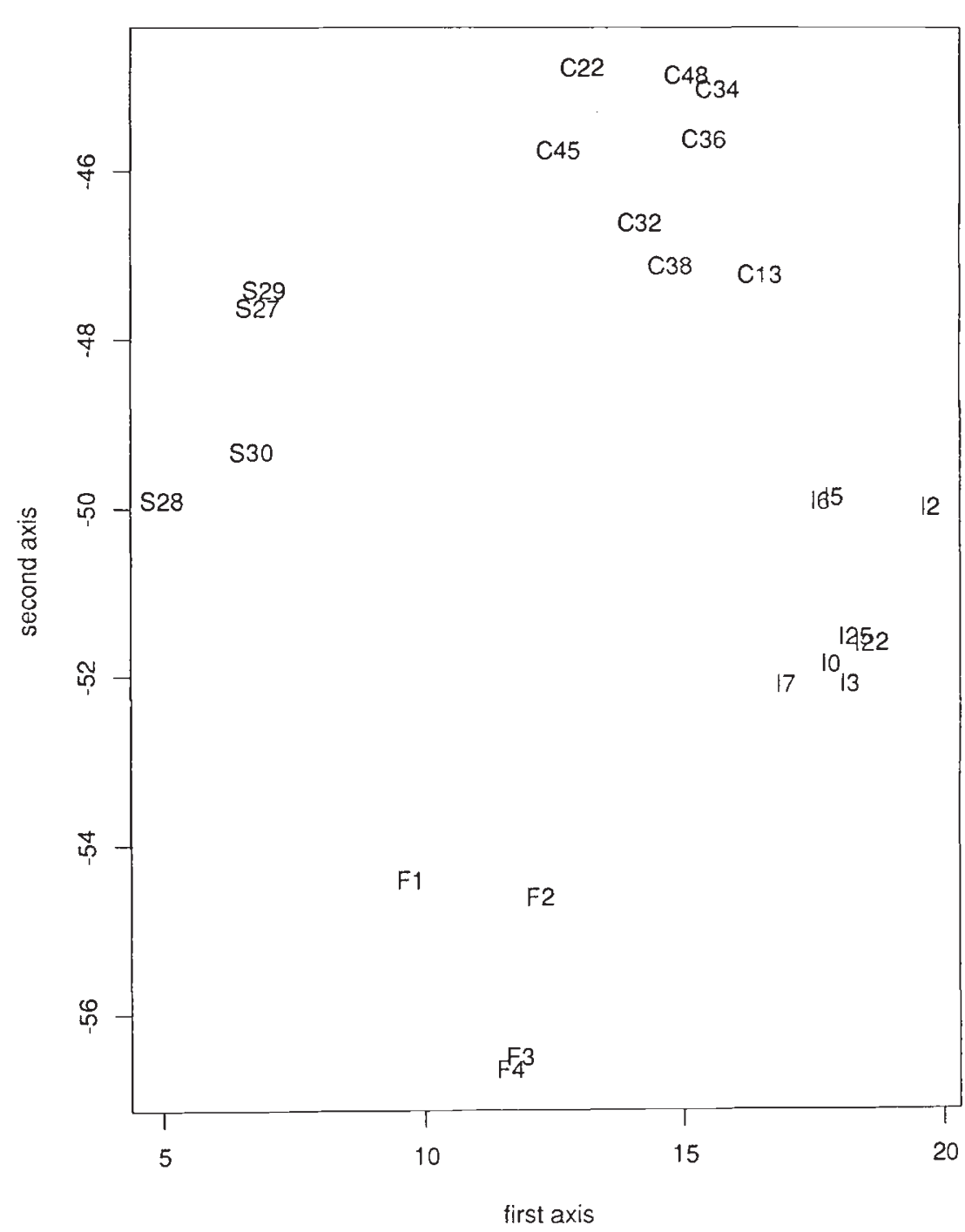

Northern Spain (Oliveira \& Charmet, 1989). Our diversity indices, presented in Table 2, are consistent with those reported by these authors. In fact, although the results do not differ significantly between populations (because only a small number of populations were sampled from France and Sardinia), Table 2 indicates that on average French populations show lower diversity indices than Corsican accessions. These results are consistent with those found by Charmet et al. (1993), from a sample of 60 wild populations collected throughout France. This could be explained by the fact that the centre of origin of the genus Lolium is nearer to the Mediterranean regions of Corsica and Italy than to France.

We can hypothesize that perennial ryegrass was introduced from the continent into Corsica. The apparent lack of reduction in genetic diversity indices in the introduced populations (i.e. Corsican), compared with those of the continent, could be explained by the fact that Lolium perenne is an outbreeding species with high effective population size. As shown by Table 3 , most of the variation is contained within the population and even a small founding sample from a random population may carry a high proportion of the variation of the introduced species. This explanation has been checked on other outbreeding species, for instance Echium plantagineum, introduced from Europe to Australia (Burdon \& Brown, 1986), or Apera spicaven$t i$, introduced from Europe to Canada (Warwick et al., 1987).

\section{Geographical pattern}

Mediterranean areas have always been the seat of important human migrations and colonizations. The island of Corsica was firstly colonized by Phoceans in 
$500 \mathrm{BC}$ and then by the Romans in the first century. Agricultural and commercial development was mainly introduced by the citizens of Genova at the end of the 13th century (Caratini, 1981), and finally, Corsica was transferred to France during the 18th century.

The hypothesis of the introduction of perennial ryegrass from Italy to Corsica is reinforced by the phenogram (Fig. 2), devised from genetic similarity calculated using all the loci. From this, we can observe that Corsican and Italian accessions belong to the same cluster with population no. $\mathrm{C} 13$, from Aleria, showing more similarity to Italian accessions than to its neighbouring Corsican accessions. This last observation can be explained by considering the history of the location of C13: Aleria was in the past the most important harbour of the Corsican eastern coast where immigrants landed from Italy. By contrast, accession no. C22 is more similar to French populations, probably due to its location on the north-west coast of the island, close to the French Riviera.

The clear differences between the French and Italian populations, despite their close proximity, can be explained by the fact that the two countries are divided by the Alps which probably act as a natural barrier to gene flow between them.

Finally, Sardinian accessions appear very different from continental material (Table 4) and, to a lesser extent, from Corsican populations although only a few kilometres separate the two islands. Certainly, it would have been interesting to compare them with Sicilian accessions; unfortunately, no perennial ryegrass seed from Sicily is available at the present time.

Certain alleles, such as $A C P-2-b$, show clinal geographical variation: Fig. 3 indicates a clinal trend from north (France, Italy) to south (Corsica, then Sardinia) which may suggest a migration from continental populations, rich in $A C P-2-b$, towards Corsica and Sardinia.

Sardinian material also presents some rare alleles such as $P G M-c$ or $M D H-a^{+}$. According to recent results (Charmet \& Balfourier, 1993), we know that these alleles are more frequent in the other cross-pollinated species, Lolium multiflorum and Lolium rigidum. The presence of such rare alleles in Sardinia may result from introgression between these species and L. perenne (Terell, 1968), hence providing an explanation of the diversity of the four populations studied here, compared with the others. In fact, the island of Sardinia is actually located at the border of the extension area of the three species and another cause of local differentiation could be a genetic drift due to the founding of new populations by a small number of founders (bottleneck effect).

The multivariate analyses support our hypothesis concerning the relationships between the different accessions according to their geographical origin. It is quite interesting to observe that it is possible to distinguish and discriminate so easily the geographical origin of such a small sample of wild populations of perennial ryegrass, using only 13 loci.

In this study, historical and geological occurrences are in agreement with the hypothesis of migration from the continent to the islands. It would be interesting to study the evolutionary process of the genus Lolium at a larger geographical scale, again using such markers. This survey is under investigation at present.

\section{Acknowledgements}

The authors wish to thank Dr S. Bullitta (Sassari, Italy) and Dr M. Falcinelli (Perugia, Italy), who have kindly provided us with some of the accessions used in this study.

\section{References}

ARCONI, S., F. DIAMANI, D. MARIOTTI, M. PEZZOTTI, AND CARPINELLI, G. 1988. Enzymatic polymorphism and ecological environment in Italian land race populations of Lolium perenne Agric. Mediterranea, 118, 166-176.

BALFOURIER, F. AND CHARMET, G. 1991. Spaced plant evaluation of Mediterranean germplasm collections of perennial ryegrass. Euphytica, 57, 57-66.

BECKER, R. A., CHAMBERS, J. M. AND wILKs, A. R. 1988. The new $S$ language. A programming environment for data analysis and graphics. Wadsworth and Brooks/Cole Advanced Books and Software. Pacific Grove California.

BORILL, M. 1976. Temperate grasses. In: Simmonds N. W. (ed), Evolution of Crop Plants, Largam, London, pp. 137-142.

BURDON, J. J. AND BROWN, A. H. D. 1986. Population genetics of Echium plantagineum L. - target weed for biological control. Aust. J. Biol. Sci., 39, 369-378.

CARATINI, R. 1981. Histoire de la Corse. Bordas Paris.

CHARMET, G. AND BALFOURIER, F. 1993. Isozyme variation and species relationships in the genus Lolium L. (ryegrasses Graminaceae). Theor. Appl. Genet., (in press).

CHARMET, G., BALFOURIER, F. AND BION, A. 1990. Agronomic evaluation of a collection of French perennial ryegrass populations: multivariate classification using genotype $\times$ environment interactions. Agronomie, 10 , 807-823.

CHARMET, G., BALFOURIER, F. AND RAVEL, C. 1993. Isozyme polymorphism and geographic differentiation in a collection of French perennial ryegrass populations. Genet. Res. Crop. Evol. (in press).

DUCOUSSO, A., PETT, D., VALERo, M. AND VERNET, P. 1990. Genetic variation between and within populations of a perennial grass: Arrhenatherum elatius. Heredity 65, 179-188.

ENNOS, R. A. 1985. The mating system and genetic structure in a perennial grass: Cynosurus cristatus. Heredity, 55, 121-126. 
EUCARP1A, natural variation and breeding for adaptation. In: Proceedings (Lusignan, France, 22-24 September 1987,) pp. 23-35.

FALCINELL1, M., VERONESI, F. AND LORENZETTI, S. 1987. Evaluation of an Italian germplasm collection of Lolium perenne L. through a multivariate approach.

GRENECHE, M., LALLEMAND, J. AND MICHAUD, o. 1991. Comparison of different enzyme loci as a mean of distinguishing ryegrass varieties by electrophoresis. Seed. Sci. Technol., 19, 147-158.

HAMRICK, J. L. AND GODT, M. J. w. 1989. Allozyme diversity in plant species. In: Brown, Clegg, Kahler \& Weir (eds), Plant Population Genetics, Breeding and Genetic Resources, Sinauer, Sunderland MA, pp. 43-63.

HAMRICK, J. L., LINHART, Y. B. AND MITTON, J. B. 1979. Relationships between life history characteristics and electrophoretically detectable genetic variation in plants. Ann. Rev. Ecol. Syst., 10, 173-200.

HAYWARD, M. D. 1985. Adaptation, differentiation and reproductive systems in Lolium perenne. In: Jacquard, Hein and Antonovics (eds), Genetic Differentiation and Dispersal in Plants, Springer-Verlag, Berlin, NATO-ASI Series vol. 65, pp. 83-94.

HAYWARD, M. D. AND Mc ADAM, N. J. 1977. Isozyme polymorphism as a measure of distinctiveness and stability in cultivars of Lolium perenne. Z. Pflanzenzucht., 79, 59-68.

LIVESEY, v. AND NORRINGTON-DAVIES, J. 1991. Isozyme polymorphism in Festuca rubra L. Euphytica, 55, 73-79.

LUMARET, R. 1984. The role of polyploidy in the adaptative significance of polymorphism at the GOT-1 locus in the Dactylis glomerata complex. Heredity, 52, 153-169.

MALIK, C. P. 1967. Cytogenetic studies of the $F_{2}$ hybrid of $L$. multiflorum $\times L$. rigidum and the species relationships in the genus Lolium. Der Zuchter, 37, 261-274.

oliveirA, J. A. AND CHARMET, G. 1989. Polimorfismo isoenzymatico de seis poblaciones naturales de raigras ingles de Galicia. Revista Pastos, 18-19, 69-85.

ostegaARD, H., NIELSEN, G. AND JOHANSEN, H. 1985. Genetic variation in cultivars of diploid ryegrass, Lolium perenne and Lolium multiflorum, at five enzyme systems. Theor. Appl. Genet., 69, 409-421.
POLLANS, N. O. AND ALLARD, R. w. 1985. Inheritance of electrophoretically detectable variants in ryegrass. J. Hered., 76, $61-62$.

RAVEL, C., CHARMET, G. AND BALfourier, F. 1992. A database for a more efficient perennial ryegrass breeding programma. Euphytica, 61, 145-151.

ROGERS, 3. S. 1972. Measures of genetics, similarity and genetic distance. Studies in Genetics, University of Texas Publication 7213, pp. 145-153.

SNEATH, P. H. A. AND SOKAL, R. R. 1973. Numerical Taxonomy. W. H. Freeman, San Francisco.

SWOFFORD, D. L. AND SELANDER, R. B. 1981. Biosys 1: a Fortran Program for the comprehensive analysis of electrophoretic data in population genetics and systematics. J. Hered., 72, 81-83.

TERELL, E. E. 1968. A taxonomic revision of the genus Lolium. Technical Bulletin US Department of Agriculture 1392, pp. 1-65.

TOMASSONNE, R., DANZART, M., DAUDIN, J. J. AND MASSON, J. P. 1988. Discrimination et Classement. Masson, Paris.

TYLER, B. F. AND CHORLTON, K. H. 1978. A Lolium and Festuca plant collecting expedition to northern Italy. Rev. Agron., 12, 181-190.

TYLER, B. F., CHORLTON, K. H. AND THOMAS, 1. D. 1984. Characterization of collected $L$. perenne populations. Report Welsh Plant Breeding Station 1983, Aberystwyth (U.K.), pp. 29-32.

VOLAIRE, F., GODRON, M. AND LELIEVRE, F. 1990. Les formations herbacées en Corse. I. Elaboration d'une typologie mérologique et floristique. Agronomie, 10, 163-174.

WARWICK, S. I., THOMPSON, B. K. AND BLACK, L. D. 1987. Genetic variation in Canadian and European populations of the colonizing weed species Apera spicaventi. New Phytol., 106, 301-317.

WRIGHT, s. 1965. The interpretation of population structure by F-statistics with special regard to systems of mating. Evolution, 19, 395-420.

WR1GHT, s. 1978. Evolution and the Genetics of Populations, vol. 4, Variability Within and Among Natural Populations. University of Chicago Press, Chicago. 